\title{
Plastic debris in 29 Great Lakes tributaries: Relations to watershed attributes and hydrology
}

\section{Supporting Information}

Austin K. Baldwin ${ }^{a} *$, Steven R. Corsi ${ }^{a}$, Sherri A. Mason ${ }^{b}$

${ }^{a}$ U.S. Geological Survey, 8505 Research Way, Middleton, WI 53562, USA.

${ }^{\mathrm{b}}$ State University of New York at Fredonia, Department of Chemistry and Biochemistry, 280 Central Ave., Science Complex 340, Fredonia, NY 14063, USA.

*Corresponding author; current address: U.S. Geological Survey, 230 Collins Rd., Boise, ID 83702, USA. akbaldwi@usgs.gov

Email addresses: akbaldwi@usgs.gov (A.K. Baldwin), srcorsi@usgs.gov (S.R. Corsi), mason@fredonia.edu (S.A. Mason)

\author{
Contents

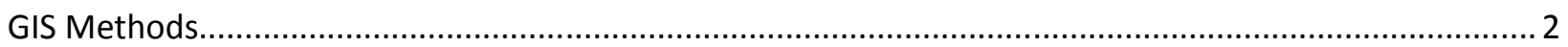

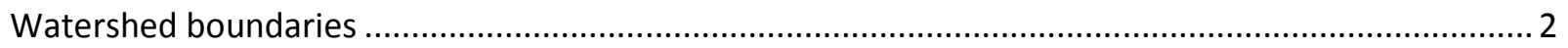

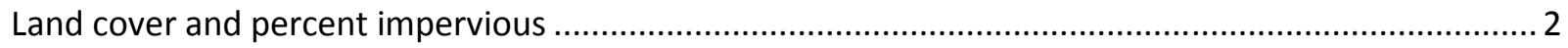

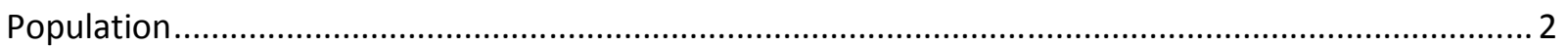

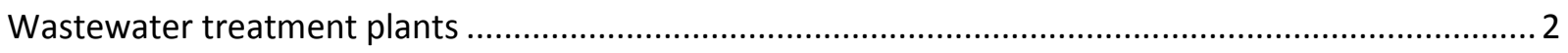

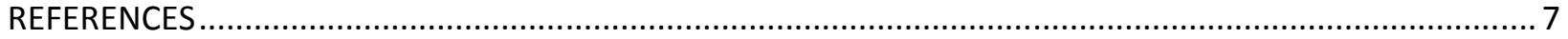

\section{Tables and figures}

SI-Table 1. Site characteristics, land cover, and wastewater influence.

SI-Figure 1. Plastic particles recovered from field blank samples $(n=5)$ compared to environmental samples $(n=107)$.

SI-Table 2. Plastic concentrations at 29 Great Lakes tributaries, 2014-15.

SI-Figure 2. Plastic concentrations and the percentage of streamflow from wastewater treatment plant (WWTP) effluent. 
SI-Table 1. Site characteristics, land cover, and wastewater influence. Drainage areas are from USGS National Water Information System (NWIS) unless unavailable, then GIS computed (indicated with ${ }^{\mathrm{A}}$ ). Annual mean flow is mean for Oct 2013 - Sept 2014, in cubic feet per second (cfs). Basin population from US Census, 2010. Land cover from National Land Cover Database 2011. Wastewater treatment plant (WWTP) statistics are a combination of data from the USGS SPARROW Program and the International Joint Commission. WWTP effluent contribution to streamflow is based on annual means; contributions corresponding to individual samples vary. [ $\mathrm{mi}^{2}$, square miles; ID, identification] (see separate file-table does not fit here)

\section{GIS Methods}

\section{Watershed boundaries}

Watershed boundaries were derived from the USGS Watershed Boundary Dataset (WBD) ${ }^{1}$.

\section{Land cover and percent impervious}

Land cover statistics and percent imperviousness were determined using the 2011 versions of the 2001, 2006, and 2011 National Land Cover Database (NLCD) Land Cover and Percent Developed Imperviousness datasets ${ }^{2-5}$; zonal statistics were calculated using ArcView Version 3.3. Land cover summaries done here corresponded with standard land cover groupings, with urban land cover represented by classes $21-24$, agriculture land cover represented by classes 81 and 82 , and other land cover represented by all remaining classes. Percent imperviousness summaries represent areaweighted means of the impervious percentages found within each watershed.

\section{Popullation}

Population was determined using the U.S. Census Bureau 2010 state-based block datasets ${ }^{6-12}$. These datasets contain population counts within individual, irregularly shaped polygons. To determine the total population for a given watershed, it was assumed that the population within each block was evenly distributed. The population per unit area was determined for each polygon, and this value was multiplied by the area falling within (i.e., clipped to) the watershed boundary; products were summed across polygons and the result constituted the total population assessment for that watershed.

\section{Wastewater treatment plants}


Wastewater treatment plant (WWTP) data from within permitted discharge systems in the U.S. were utilized in this assessment. These datasets were originally extracted from the U.S. Environmental Protection Agency National Pollutant Discharge Elimination System (NPDES) and Ontario Ministry of Natural Resources databases with subsequent updates and corrections-following extraction-by either the International Joint Commission (IJC) or by the U.S. Geological Survey (USGS). The IJC compiled WWTP data for both the U.S. and Canada in the Great Lakes Watershed in 2012 (Michael T. Laitta and Antonette Arvai, International Joint Commission, personnel communication, 7/29/2013) in an effort to have an international, synchronized database of accurate WWTP locations. The USGS compiled WWTP data for the United States to assist in the development of Spatially Referenced Regression on Watershed Attributes (SPARROW) models that simulate nutrient loads in streams ${ }^{13}$. The USGS is currently updating this WWTP database for use in new SPARROW models for the United States (Ken Skinner, USGS, personal communication, 3/12/15). WWTP locations utilized for these analyses were sourced from the IJC and USGS updated datasets, with preference given to locational information in the IJC dataset, as available. Intersection of sampling sites and WWTP points with NHDPlus catchment shapefiles allowed for calculation of distances between the downstream ends of the respective catchments, through the use of value added attributes in the latter file; in instances where watershed boundaries differed from data available through NHDPlus (as confirmed through local knowledge), manual measurements were made in comparison with available aerial imagery. Attributes from these datasets were used to characterize WWTPs within each site's watershed. 


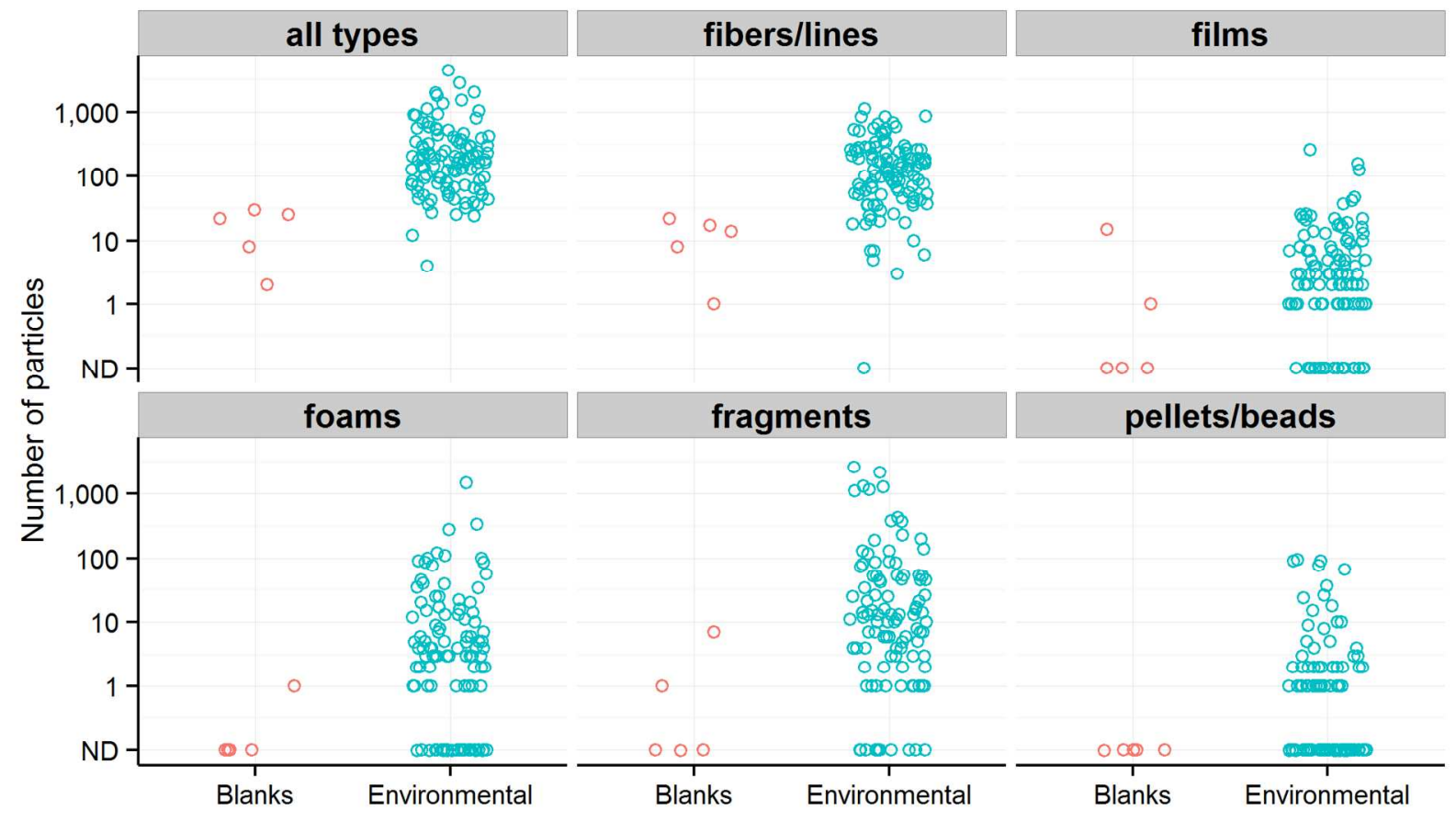

SI-Figure 1. Plastic particles recovered from field blank samples $(n=5)$ compared to environmental samples $(n=107)$. 
SI-Table 2. Plastic concentrations at 29 Great Lakes tributaries, 2014-15. Complete results are published separately ${ }^{14}$.

\begin{tabular}{|c|c|c|}
\hline \multirow[b]{2}{*}{ Sampling location } & \multicolumn{2}{|c|}{$\begin{array}{c}\text { concentration, in } \\
\text { particles } / \mathrm{m}^{3}\end{array}$} \\
\hline & median & $\max$ \\
\hline St Louis, MN & 0.8 & 1.2 \\
\hline Nemadji, WI & 0.9 & 5.4 \\
\hline Fox, WI & 3.7 & 7.7 \\
\hline Manitowoc, WI & 0.7 & 1.1 \\
\hline Sheboygan, WI & 0.6 & 2.6 \\
\hline Milwaukee, WI & 5.5 & 17.3 \\
\hline Indiana $\mathrm{HC}, \mathrm{IN}$ & 7.1 & 13.5 \\
\hline Burns, IN & 0.3 & 0.5 \\
\hline St Joseph, MI & 1.8 & 7.3 \\
\hline Paw Paw, MI & 7.0 & 7.4 \\
\hline Kalamazoo, $\mathrm{Ml}$ & 1.5 & 3.8 \\
\hline Grand, MI & 3.4 & 7.5 \\
\hline Saginaw, MI & 4.0 & 9.7 \\
\hline Clinton, MI & 12.2 & 21.5 \\
\hline Rouge, MI & 10.2 & 11.4 \\
\hline Huron, MI & 1.3 & 32.3 \\
\hline Raisin, MI & 0.5 & 4.4 \\
\hline Maumee, $\mathrm{OH}$ & 2.6 & 4.1 \\
\hline Portage, $\mathrm{OH}$ & 1.7 & 3.1 \\
\hline Sandusky, $\mathrm{OH}$ & 2.1 & 6.4 \\
\hline Huron, $\mathrm{OH}$ & 1.0 & 2.0 \\
\hline Black, OH & 1.2 & 1.9 \\
\hline Rocky, OH & 2.6 & 5.4 \\
\hline Cuyahoga, $\mathrm{OH}$ & 2.6 & 7.3 \\
\hline Grand, $\mathrm{OH}$ & 1.2 & 3.1 \\
\hline Ashtabula, $\mathrm{OH}$ & 10.3 & 23.2 \\
\hline Buffalo, NY & 4.1 & 31.1 \\
\hline Tonawanda, NY & 3.3 & 4.6 \\
\hline Genesee, NY & 2.0 & 12.0 \\
\hline
\end{tabular}



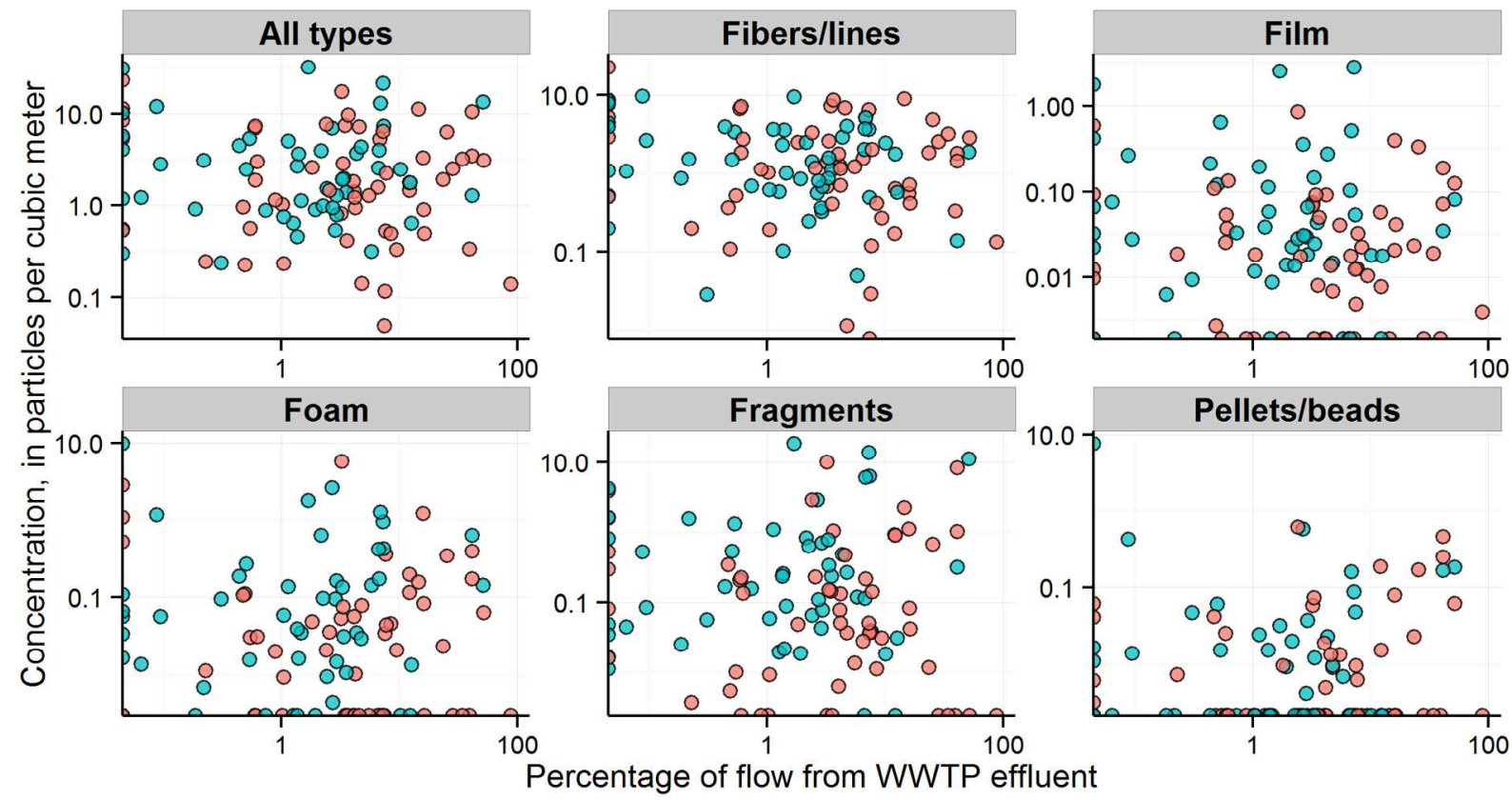

low-flow 0 runoff

SI-Figure 2. Plastic concentrations and the percentage of streamflow from wastewater treatment plant (WWTP) effluent. 


\section{REFERENCES}

(1) U.S. Department of Agriculture-Natural Resources Conservation Service; U. S. Geological Survey; U.S Environmental Protection Agency. The Watershed Boundary Dataset (WBD); Vector digital data; Fort Worth, Texas, 2009.

(2) Homer, C.; Dewitz, J.; Fry, J.; Coan, M.; Hossain, N.; Larson, C.; Herold, N.; McKerrow, A.; VanDriel, J. N.; Wickham, J. Completion of the 2001 National Land Cover Database for the Conterminous United States. Photogramm. Eng. Remote Sens. 2007, 73 (4), 337.

(3) Fry, J.; Xian, G.; Jin, S.; Dewitz, J.; Homer, C.; Yang, L.; Barnes, C.; Herold, N.; Wickham, J. Completion of the 2006 National Land Cover Database for the Conterminous United States. Photogramm. Eng. Remote Sens. 2011, 77 (9), 858-864.

(4) Jin, S.; Yang, L.; Danielson, P.; Homer, C.; Fry, J.; Xian, G. A comprehensive change detection method for updating the national land cover database to circa 2011. Remote Sens. Environ. 2013, 132, 159-175.

(5) Xian, G.; Homer, C.; Demitz, J.; Fry, J.; Hossain, N.; Wickham, J. Change of impervious surface area between 2001 and 2006 in the conterminous United States. Photogramm. Eng. Remote Sens. 2011, 77 (8), $758-762$.

(6) U.S. Census Bureau Geography Division. 2010 State-based Census Block TIGER/Line Shapefile (Wisconsin), 2010.

(7) U.S. Census Bureau Geography Division. 2010 State-based Census Block TIGER/Line Shapefile (Minnesota), 2010.

(8) U.S. Census Bureau Geography Division. 2010 State-based Census Block TIGER/Line Shapefile (Michigan), 2010.

(9) U.S. Census Bureau Geography Division. 2010 State-based Census Block TIGER/Line Shapefile (New York), 2010.

(10) U.S. Census Bureau Geography Division. 2010 State-based Census Block TIGER/Line Shapefile (Ohio), 2010.

(11) U.S. Census Bureau Geography Division. 2010 State-based Census Block TIGER/Line Shapefile (Indiana), 2010.

(12) U.S. Census Bureau Geography Division. 2010 State-based Census Block TIGER/Line Shapefile (Pennsylvania), 2010.

(13) Maupin, M. A.; Ivahnenko, T. Nutrient Loadings to Streams of the Continental United States from Municipal and Industrial Effluent. JAWRA J. Am. Water Resour. Assoc. 2011, 47 (5), 950-964.

(14) Baldwin, A. K.; Corsi, S. R.; Mason, S. A. Microplastics in 29 Great Lakes tributaries (2014-15) https://www.sciencebase.gov/catalog/item/5748a29be4b07e28b664dd62 (accessed May 31, 2016). 